\title{
The host cellular immune response to cytomegalovirus targets the endothelium and is associated with increased arterial stiffness in ANCA-associated vasculitis
}

Dimitrios Chanouzas ${ }^{1,2^{*}}$ D, Michael Sagmeister ${ }^{1,2}$, Lovesh Dyall ${ }^{2}$, Phoebe Sharp ${ }^{1,2}$, Lucy Powley², Serena Johal ${ }^{1,2}$, Jessica Bowen ${ }^{2}$, Peter Nightingale ${ }^{3}$, Charles J. Ferro ${ }^{2,3}$, Matthew D. Morgan ${ }^{2,4}$, Paul Moss $5^{5}$ and Lorraine Harper ${ }^{2,3,4}$

\begin{abstract}
Background: Cardiovascular disease is a leading cause of death in ANCA-associated vasculitis (AAV). An expansion of $\mathrm{CD}^{+} \mathrm{CD} 28^{\text {null }} T$ cells is seen mainly in cytomegalovirus (CMV)-seropositive individuals and has been linked to increased cardiovascular disease risk in other conditions. The aims of this study were to phenotype $C D 4^{+} C D 28^{\text {null }} T$ cells in AAV with respect to their pro-inflammatory capacity and ability to target and damage the endothelium and to investigate their relationship to arterial stiffness, a marker of cardiovascular mortality.

Methods: $\mathrm{CD}^{+} \mathrm{CD} 28^{\text {null }} \mathrm{T}$ cells were phenotyped in $53 \mathrm{CMV}$-seropositive AAV patients in stable remission and 30 age-matched CMV-seropositive healthy volunteers by flow cytometry following stimulation with CMV lysate. The expression of endothelial homing markers and cytotoxic molecules was evaluated in unstimulated $C D 4^{+} C D 28^{\text {null }} T$ cells. Arterial stiffness was measured by carotid-to-femoral pulse wave velocity (PWV) in patients with AAV.

Results: $C D 4^{+} C D 28^{\text {null }} T$ cells were CMV-specific and expressed a T helper 1 (Th1) phenotype with high levels of interferon-gamma (IFN- $\gamma$ ) and tumour necrosis factor-alpha (TNF-a) secretion. They also co-expressed the endothelial homing markers CX3CR1, CD49d and CD11b and cytotoxic molecules perforin and granzyme B. CD4 ${ }^{+} C D 28^{\text {null }} T$ cells were phenotypically similar in patients with $\mathrm{AAV}$ and healthy volunteers but their proportion was almost twice as high in patients with AAV (11.3\% [3.7-19.7] versus 6.7 [2.4-8.8]; $P=0.022)$. The size of the CD4 ${ }^{+} C D 28^{\text {null }} T$-cell subset was independently linked to increased PWV in AAV $\left(0.66 \mathrm{~m} / \mathrm{s}\right.$ increase per $10 \%$ increase in $\mathrm{CD}^{+} \mathrm{CD} 28^{\text {null }}$ cells, $95 \%$ confidence interval 0.13-1.19; $P=0.016$ ).

Conclusion: The host cellular immune response to CMV leads to the expansion of cytotoxic $C D 4^{+} C D 28^{\text {null }} T$ cells that express endothelial homing markers and are independently linked to increased arterial stiffness, a marker of cardiovascular mortality. Suppression of CMV in AAV may be of therapeutic value in reducing the risk of cardiovascular disease.
\end{abstract}

Keywords: ANCA, Vasculitis, Cytomegalovirus, Inflammation, T cells, Arterial stiffness, Cardiovascular disease

\footnotetext{
* Correspondence: d.chanouzas@bham.ac.uk

1 Institute of Inflammation and Ageing, College of Medical and Dental

Sciences, University of Birmingham, Birmingham B15 2TT, UK

${ }^{2}$ Renal Unit, University Hospitals Birmingham NHS Foundation Trust,

Mindelsohn Way, Edgbaston, Birmingham B15 2TH, UK

Full list of author information is available at the end of the article
}

(c) The Author(s). 2018 Open Access This article is distributed under the terms of the Creative Commons Attribution 4.0 International License (http://creativecommons.org/licenses/by/4.0/), which permits unrestricted use, distribution, and reproduction in any medium, provided you give appropriate credit to the original author(s) and the source, provide a link to the Creative Commons license, and indicate if changes were made. The Creative Commons Public Domain Dedication waiver (http://creativecommons.org/publicdomain/zero/1.0/) applies to the data made available in this article, unless otherwise stated. 


\section{Background}

Inflammation is a key factor in the pathophysiology of atherosclerosis $[1,2]$. The relationship between inflammation and cardiovascular disease (CVD) is evident in patients with rheumatic disorders such as rheumatoid arthritis, systemic lupus erythematosus and ANCA-associated vasculitis (AAV), in which CVD is a leading cause of death [3-5]. Traditional risk factors do not fully explain the increased incidence of CVD seen in these conditions [6], and it is thought that inflammation and immunopathology may accelerate atherosclerosis [7].

CD4 T cells that do not express the co-stimulatory molecule $\mathrm{CD} 28\left(\mathrm{CD}_{4}^{+} \mathrm{CD} 28^{\text {null }}\right)$ have been implicated in vascular injury [8]. $\mathrm{CD} 44^{+} \mathrm{CD} 28^{\text {null }} \mathrm{T}$ cells are pro-inflammatory and their proportion expands under inflammatory conditions [9-11]. They are found preferentially in unstable rather than stable atherosclerotic plaques [12], suggesting direct involvement in plaque disruption, and they have been shown in in vitro assays to exhibit endothelial cytotoxicity in the context of acute coronary syndrome [13] and AAV [14]. Several studies in patients with inflammatory disorders such as rheumatoid arthritis have demonstrated that expansion of $\mathrm{CD} 4{ }^{+} \mathrm{CD} 28^{\text {null }} \mathrm{T}$ cells is independently associated with increased incidence of CVD and cardiovascular mortality [15-19].

Loss of the co-stimulatory molecule CD28 on CD4 T cells suggests repeated exposure to a persistent antigen [20]. We and others have demonstrated that significant expansion of $\mathrm{CD} 4^{+} \mathrm{CD} 28^{\text {null }} \mathrm{T}$ cells occurs mainly in cytomegalovirus (CMV)-seropositive individuals, and negligible or very low proportions of these cells are seen in the absence of previous CMV infection [11, 21-24]. CMV infection is widely prevalent in the general population [25], and CMV itself has been implicated in the pathogenesis of CVD [26]. CMV infects endothelial and smooth muscle cells where it is able to persist during latency [27]. Infection with $\mathrm{CMV}$ is associated with impaired vascular function [28], high blood pressure [29], increased arterial stiffness [30] and cardiovascular mortality [26]. Furthermore, a recent meta-analysis demonstrated that CMV infection is associated with a $22 \%$ increased relative risk for CVD in the general population [31].

The aims of this study were to characterise the phenotype of $\mathrm{CD} 4{ }^{+} \mathrm{CD} 28^{\text {null }} \mathrm{T}$ cells in $\mathrm{AAV}$, with respect to their pro-inflammatory capacity and ability to target and damage the endothelium, and to determine whether expansion of this cell subset is associated with arterial stiffness, a marker of cardiovascular mortality.

\section{Methods}

\section{Study population}

Fifty-three CMV-seropositive patients with AAV in stable remission were recruited from the vasculitis clinic at University Hospitals Birmingham NHS Foundation Trust (Birmingham, UK), and 30 age-matched CMVseropositive healthy volunteers $(\mathrm{HVs})$ were enrolled from the 1000 Elders Cohort (courtesy of Professor Janet Lord, University of Birmingham, UK) and patient household contacts. $\mathrm{CD} 44^{+} \mathrm{CD} 28^{\text {null }}$ T-cell percentage and phenotype were assessed in all participants. Arterial stiffness was measured in patients with AAV.

Patients were eligible for inclusion if they had a documented diagnosis of AAV and were in stable remission for at least 6 months, on maintenance immunosuppression with a maximum of two agents, and seropositive for CMV (anti-CMV IgG detected in peripheral blood). Exclusion criteria were estimated glomerular filtration rate of less than $15 \mathrm{~mL} /$ minute per $1.73 \mathrm{~m}^{2}$, B cell-depleting therapy within 12 months or $\mathrm{T}$ cell-depleting therapy within 6 months, presence of other chronic infection (HIV, hepatitis B, hepatitis $\mathrm{C}$, or tuberculosis) and treatment with anti-CMV therapies within the previous month.

Thirty-eight of 53 patients with AAV were participants in the 'Cytomegalovirus modulation of the immune system in ANca-associated VASculitis' (CANVAS) clinical trial, a proof-of-concept open-label randomised trial of valaciclovir, or no additional treatment, in CMV-seropositive AAV patients in remission [32]. All immune and arterial stiffness assessments reported here were conducted at baseline prior to commencement of valaciclovir.

The study was approved by the Research Ethics Committee of Yorkshire and the Humber (UK). Written informed consent was obtained from all participants.

\section{Blood collection}

Up to $50 \mathrm{~mL}$ of peripheral blood was obtained and processed within a maximum of 5 hours following venepuncture. Plasma was isolated by centrifugation and cryopreserved at $-80{ }^{\circ} \mathrm{C}$. Peripheral blood mononuclear cells (PBMCs) were isolated from heparinised blood by density gradient centrifugation, used immediately in stimulation experiments with CMV lysate to identify cytokine-producing $\mathrm{T}$ cells, or cryopreserved in liquid nitrogen.

Cells for flow cytometry experiments were acquired on a BD LSR II Flow Cytometer and analysed by using FACS DIVA Software Version 8.0 (BD, Franklin Lakes, NJ, USA). Monoclonal antibodies used for flow cytometry experiments are listed in Table S1 of Additional file 1. Gating strategies are shown in Figure $\mathrm{S} 1$ and $\mathrm{S} 2$ of Additional file 1.

\section{Enumeration of peripheral blood $\mathrm{CD} 4{ }^{+} \mathrm{CD} 28^{\text {null }} \mathrm{T}$ cells}

Whole blood was stained with anti-CD3, anti-CD4 and anti-CD28 monoclonal antibodies to determine $\mathrm{CD} 4{ }^{+} \mathrm{CD} 28^{\text {null }}$ T-cell percentage. Quality control was 
achieved by using a positive control (Cytofix CD4 Normal Range Positive Control; Cytomark, Caltag Medsystems, Buckingham, UK) with a validated acceptance range for $\mathrm{CD}^{+} \mathrm{CD}^{+}$percentage and a fluorescence minus one control to aid CD28 gating. These were assayed with every analytical run.

\section{Peripheral blood mononuclear cell stimulation}

To identify CMV lysate-stimulated cytokine-expressing $\mathrm{T}$ cells, $0.5-1 \times 10^{6}$ PBMCs were re-suspended in supplemented medium-(RPMI), $10 \%$ foetal calf serum; sterile filtered and heat inactivated (Sigma-Aldrich, St. Louis, MO, USA), $1 \%$ penicillin/streptomycin (P/S) (Gibco, Thermo Fisher Scientific, Waltham, MA, USA-overnight for $16( \pm 2)$ hours at $37{ }^{\circ} \mathrm{C}, 5 \% \mathrm{CO}_{2}$, in the presence of monensin $(2 \mu \mathrm{mol} / \mathrm{L})$ and phycoerythrin-conjugated anti-CD154 monoclonal antibody as previously described [33]. Cells were stimulated with CMV lysate (1:100) prepared from CMV strain AD169-infected human foetal foreskin fibroblasts. Unstimulated cells served as controls. Following overnight incubation, cells were stained with eFluor-506 viability dye (eBioscience, Thermo Fisher Scientific) for $30 \mathrm{~min}$ at $4{ }^{\circ} \mathrm{C}$, washed with phosphate-buffered saline and flow cytometry buffer, and co-stained with saturating amounts of anti-CD3, anti-CD4 and anti-CD28 antibodies for $30 \mathrm{~min}$ at $4{ }^{\circ} \mathrm{C}$ before washing with flow cytometry buffer. Cells were fixed and permeabilised with an intracellular flow cytometry staining kit (eBioscience) and stained for $30 \mathrm{~min}$ at $4{ }^{\circ} \mathrm{C}$ with saturating amounts of anti-interferon-gamma (anti-IFN- $\gamma$ ), anti-tumour necrosis factor-alpha (anti-TNF- $\alpha$ ), anti -interleukin-2 (anti-IL-2), anti-IL-5, anti-IL-10 and anti-T-bet monoclonal antibodies before washing with flow cytometry buffer.

\section{Identification of Th1-, Th2- and Th17-skewed subsets}

The expression of chemokine receptors on unstimulated $\mathrm{CD} 4{ }^{+} \mathrm{CD} 28^{\text {null }} \mathrm{T}$ cells from 17 patients with AAV was defined by staining whole blood with anti-CXCR3, anti-CCR4, anti-CCR6, anti-CD3, anti-CD4 and anti-CD28 monoclonal antibodies. T helper 1 (Th1)-skewed CD4 T cells were identified as $\mathrm{CXCR}^{+}{ }^{+} \mathrm{CCR}^{-}$, Th2-skewed as $\mathrm{CCR}^{+}{ }^{+} \mathrm{CCR}^{-}$and Th17-skewed as CCR4 ${ }^{+} \mathrm{CCR}^{+}{ }^{+}$[34].

\section{Identification of endothelial homing receptors and cytotoxic molecules}

In order to phenotype unstimulated $\mathrm{CD} 4{ }^{+} \mathrm{CD} 28^{\text {null }} \mathrm{T}$ cells with respect to their expression of endothelial homing receptors and cytotoxic molecules, cryopreserved PBMCs from 10 patients with AAV were stained with Fixable Viability dye eFluor-506 as described above; co-stained with anti-CD3, anti-CD4, anti-CD28, anti-CX3CR1, anti-CD49d and anti-CD11b antibodies; and fixed and permeabilised as already described, followed by intracellular staining with anti-perforin and anti-granzyme B antibodies.

\section{Measurement of soluble markers of inflammation}

Soluble markers of inflammation (IL-2, TNF- $\alpha$, IFN- $\gamma$, IL-10, IL-17A, IL-6 and highly sensitive C-reactive protein) were measured in plasma by Luminex array (ProcartaPlex, eBioscience) in accordance with the instructions of the manufacturer, read on a Bio-Rad Luminex 200 instrument (Bio-Rad, Hercules, CA, USA) and analysed by using ProcartaPlex Analyst 1.0 Software (eBioscience).

\section{Determination of anti-CMV IgG titre}

Plasma anti-CMV IgG titre was assayed by using an enzyme-linked immunosorbent assay as previously described [30]. CMV seropositivity was defined as an anti-CMV IgG titre of more than 10 units.

\section{Arterial stiffness measurement}

Arterial stiffness was estimated by measuring carotidto-femoral pulse wave velocity (PWV) using the non-invasive, non-operator-dependent Vicorder system (Skidmore, Bristol, UK) that employs a volume displacement method, as previously described [32]. Briefly, the patient was allowed to rest for $5 \mathrm{~min}$ prior to inflating a 100 -mm-wide cuff on the non-dominant arm to measure peripheral blood pressure. A 30-mm-wide cuff was then placed on the neck at the level of the carotid artery and a 100-mm-wide cuff placed around the proximal thigh. The distance between the mid-clavicular point and the mid-point of the thigh cuff, the aortic path length, was measured with the patient supine. With the patient at a supine $30^{\circ}$ head-tilt position, the cuffs were inflated to $60 \mathrm{~mm} \mathrm{Hg}$. The Vicorder instrument uses the resultant oscillometric signal to extract the pulse waveforms and pulse transit time to calculate carotid-to-femoral PWV. The mean value of three consistent readings was used for subsequent analysis.

\section{Statistical analysis}

Continuous variables were summarised as medians and quartiles (unless stated otherwise) and categorical data as counts and percentages. Groups were compared with the Mann-Whitney test, the Kruskal-Wallis and Dunn's multiple comparison test, and the chi-squared or Fisher's exact test. Associations were assessed with Spearman's rank correlation. Univariable and multivariable linear regression models were constructed for variables associated with PWV. Analyses were undertaken by using SPSS Statistics Version 21 (IBM, Armonk, NY, USA) and Prism Version 5 
(GraphPad, La Jolla, CA, USA) and were two-tailed; a $P$ value of less than 0.05 was considered significant.

\section{Results}

Baseline characteristics of study participants are shown in Table 1.

\section{$\mathrm{CD} 4^{+} \mathrm{CD} 28^{\text {null }} \mathrm{T}$ cells are $\mathrm{CMV}$-specific and display a pro-} inflammatory phenotype

We initially undertook a phenotypic analysis of $\mathrm{CD} 4{ }^{+} \mathrm{CD} 28^{\text {null }} \mathrm{T}$ cells from $53 \mathrm{CMV}$-seropositive AAV patients in stable remission. PBMCs were stimulated in vitro with CMV lysate, and the proportion of CMV-specific cells within the $\mathrm{CD} 4^{+} \mathrm{CD} 28^{\text {null }}$ and $\mathrm{CD} 4{ }^{+} \mathrm{CD} 28^{+}$subfractions was determined. A greater proportion of $\mathrm{CMV}$-specific $\mathrm{T}$ cells was observed within the $\mathrm{CD} 44^{+} \mathrm{CD} 28^{\text {null }}$ population as determined by expression of the activation marker CD154 and cytokine expression: IFN- $\gamma$, TNF- $\alpha$ and IL-2 (Fig. 1a). Neither cell type expressed significant amounts of IL-5 or IL-10.

The percentage of $\mathrm{CD} 4^{+} \mathrm{CD} 28^{\text {null }} \mathrm{T}$ cells was strongly correlated with the total $\mathrm{CMV}$-specific $\mathrm{CD} 4^{+}$response (rho $=0.846, P<0.001$; Fig. $1 \mathrm{~b}$ ), indicating that the size of the $\mathrm{CD} 4{ }^{+} \mathrm{CD} 28^{\text {null }} \mathrm{T}$-cell accumulation is a good measure of the impact of CMV infection on the CD4 compartment in this population. $\mathrm{CD} 4{ }^{+} \mathrm{CD} 28^{\text {null }} \mathrm{T}$-cell percentage also correlated with the humoral response to CMV, anti-CMV IgG titre (rho $=0.324, P=0.018$; Fig. $1 \mathrm{~b}$ ).

As well as expressing IFN- $\gamma$ and TNF- $\alpha$, the majority of $\mathrm{CD} 4{ }^{+} \mathrm{CD} 28^{\text {null }} \mathrm{T}$ cells expressed the Th1 lineage transcription factor T-bet (Fig. 1c) and a Th1-skewed chemokine receptor profile $\left(\mathrm{CXCR}^{+} \mathrm{CCR}^{-}\right)$(Fig. 1d). In contrast, the chemokine receptor staining profile that identifies Th2-skewed $\left(\mathrm{CCR}_{4}^{+} \mathrm{CCR}^{-}\right)$and Th17-skewed $\left(\mathrm{CCR}^{+}{ }^{+} \mathrm{CCR} 6^{+}\right)$cells was not seen on $\mathrm{CD} 4^{+} \mathrm{CD} 28^{\text {null }} \mathrm{T}$ cells. Indeed, $\mathrm{CD} 4^{+} \mathrm{CD} 28^{\text {null }} \mathrm{T}$ cells comprised the majority of the Th1 compartment (median 51.6\%, 30.0-77.3). In addition, the percentage of $\mathrm{CD} 44^{+} \mathrm{CD} 28^{\text {null }} \mathrm{T}$ cells was strongly correlated with the overall size of the Th1 compartment (Fig. 1c), indicating that the size of the $\mathrm{CD} 4{ }^{+} \mathrm{CD} 28^{\text {null }}$ T-cell expansion in CMV-seropositive AAV patients determines the relative proportion of Th1 cells, a subset known to exert a strong pro-atherosclerotic effect [35].

There was no difference between AAV patients and age-matched CMV-seropositive HVs in the induction of CD154 expression on $\mathrm{CD} 4^{+} \mathrm{CD} 28^{\text {null }} \mathrm{T}$ cells or their cytokine expression profile following CMV lysate stimulation (Fig. 1e). However, patients with AAV had larger expansions of $\mathrm{CD} 44^{+} \mathrm{CD} 28^{\text {null }}$ T cells compared with $\mathrm{HVs}$ (11.3\% [3.7-19.7] versus $6.7[2.4-8.8] ; P=0.022)$.

\section{$\mathrm{CD} 4^{+} \mathrm{CD} 28^{\text {null }} \mathrm{T}$ cells are endothelial homing cytotoxic $\mathrm{T}$ cells}

IFN- $\gamma$ and TNF- $\alpha$ activate endothelial cells and increase surface expression of chemokines and adhesion molecules such as IFN- $\gamma$-inducible protein-10 (IP-10), fractalkine, vascular adhesion molecule-1 (VCAM-1) and intercellular adhesion molecule-1 (ICAM-1) [36]. Having identified high levels of expression of the IP-10 receptor CXCR3 on the surface of $\mathrm{CD} 44^{+} \mathrm{CD} 28^{\text {null }} \mathrm{T}$ cells, we evaluated the surface expression of the receptors for fractalkine, VCAM-1 and ICAM-1 (CX3CR1, CD49d and $\mathrm{CD} 11 \mathrm{~b}$ ) on unstimulated PBMCs from 10 patients with AAV. Co-expression of all three endothelial homing receptors was significantly more common on $\mathrm{CD}_{4}^{+}$

Table 1 Participant baseline characteristics

\begin{tabular}{|c|c|c|}
\hline & $\operatorname{AAV}(n=53)$ & $\mathrm{HV}(n=30)$ \\
\hline Age, years & $69.0[62.8-75.3]$ & $70.5[66.8-74.0]^{*}$ \\
\hline Gender, male:female & $35: 18$ & $14: 16^{*}$ \\
\hline ANCA specificity, PR3:MPO & $34: 18$ & - \\
\hline AAV disease chronicity, years & $6.0[3.2-12.0]$ & - \\
\hline Renal function eGFR, mL/min per $1.73 \mathrm{~m}^{2}$ & $53[21]$ & - \\
\hline Urine albumin-to-creatinine ratio, mg/mmol & $4.4[1.4-9.9]$ & - \\
\hline Steroids, n (\%) & $39(73.6)$ & - \\
\hline Mycophenolate mofetil, n (\%) & $14(26.4)$ & - \\
\hline Azathioprine, n (\%) & $19(35.8)$ & - \\
\hline No current immunosuppression, n (\%) & $4(7.5)$ & - \\
\hline Ever smoker, n (\%) & $26(49.1)$ & - \\
\hline Diabetes mellitus, n (\%) & $11(20.8)$ & - \\
\hline On statin treatment, $\mathrm{n}(\%)$ & $29(54.7)$ & \\
\hline
\end{tabular}

Data are displayed as median [interquartile range] apart from renal function displayed as mean [standard deviation]. Immunosuppressive treatment refers to number and percentage of patients on the respective immunosuppressive agent at the time of study entry.

${ }^{*}$ Comparison between ANCA-associated vasculitis (AAV) and healthy volunteers (HV): age (Mann-Whitney $U$ test, $\left.P=0.557\right)$, gender (Fisher's exact, $\left.P=0.106\right)$ Abbreviations: eGFR estimated glomerular filtration rate, MPO myeloperoxidase, $P R 3$ proteinase 3 


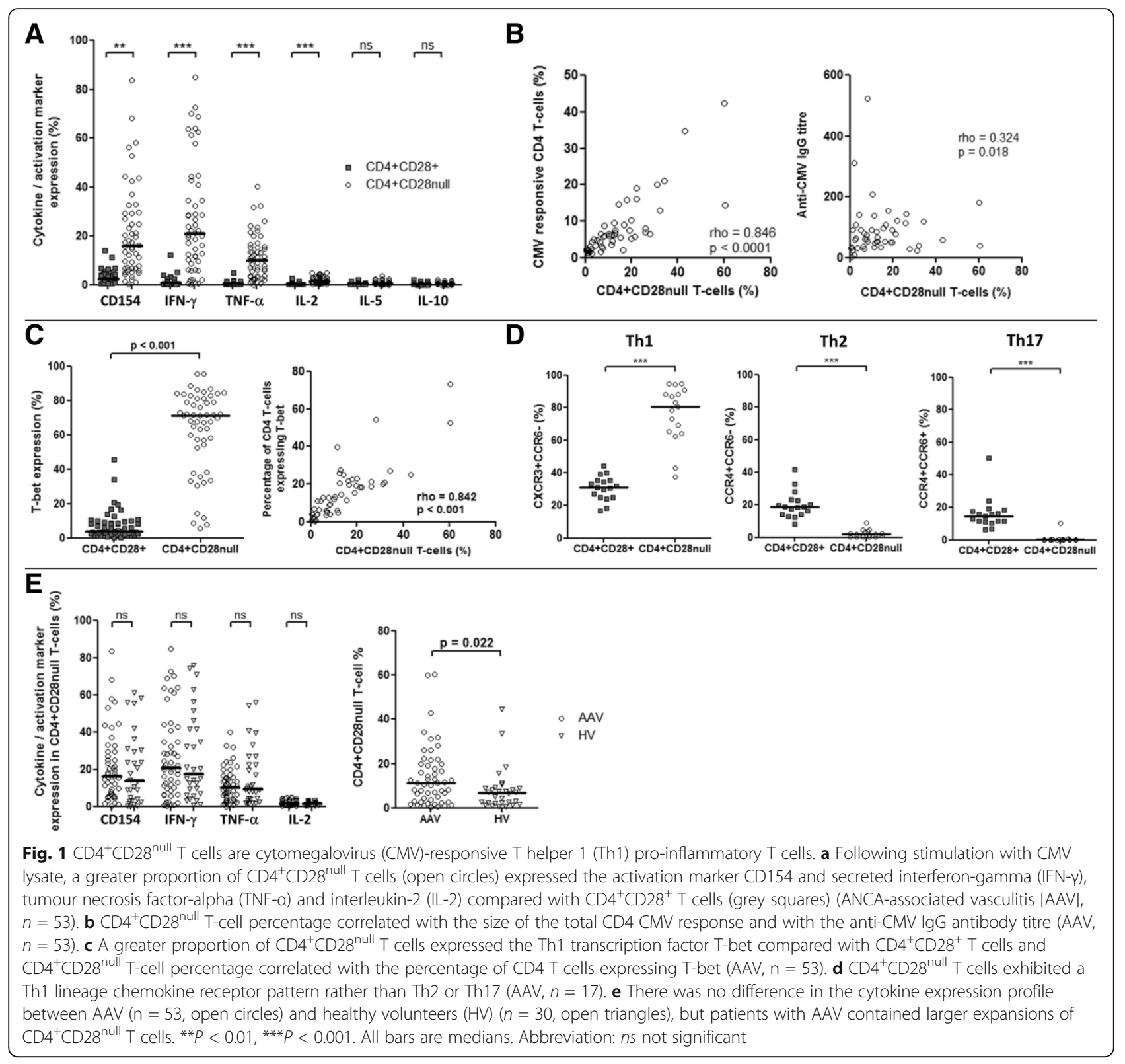

$\mathrm{CD} 28^{\text {null }}$ compared with $\mathrm{CD} 4{ }^{+} \mathrm{CD} 28^{+} \mathrm{T}$ cells $(51.6 \%$ [42.7-64.4] versus 5.0 [1.7-6.3]; $P=0.006$; Fig. 2a). In addition, the majority of unstimulated $\mathrm{CD} 4{ }^{+} \mathrm{CD} 28^{\text {null }} \mathrm{T}$ cells contained intracellular stores of both perforin and granzyme B (74.5\%, 63.5-92.7; Fig. 2b), suggesting that they have the capacity to target and lyze endothelial cells.

\section{The size of the $\mathrm{CD} 4^{+} \mathrm{CD} 28^{\text {null }} \mathrm{T}$-cell expansion is independently associated with increased arterial stiffness in AAV}

To determine whether the size of the $\mathrm{CD} 44^{+} \mathrm{CD} 28^{\text {null }}$ T-cell expansion is associated with arterial stiffness, as a clinical marker of cardiovascular pathology, carotid- to-femoral PWV was measured in the patients with $\mathrm{AAV}$. The $\mathrm{CD} 4^{+} \mathrm{CD} 28^{\text {null }}$ T-cell percentage was found to be significantly correlated with increased systolic blood pressure (rho $=0.305, P=0.026$ ), pulse pressure (rho $=0.428, P=0.001)$ and PWV (rho $=0.371$, $P=0.006$; Fig. 3).

On univariable analysis, age, percentage of $\mathrm{CD} 4^{+}$ CD28 $8^{\text {null }} \mathrm{T}$ cells, plasma concentration of TNF- $\alpha$, and blood pressure parameters (Table 2) were associated with increased PWV. In contrast, we did not observe an association between anti-CMV IgG titre and PWV.

To account for confounding factors, we constructed a multivariable linear regression model including all variables that were associated with PWV on univariable 

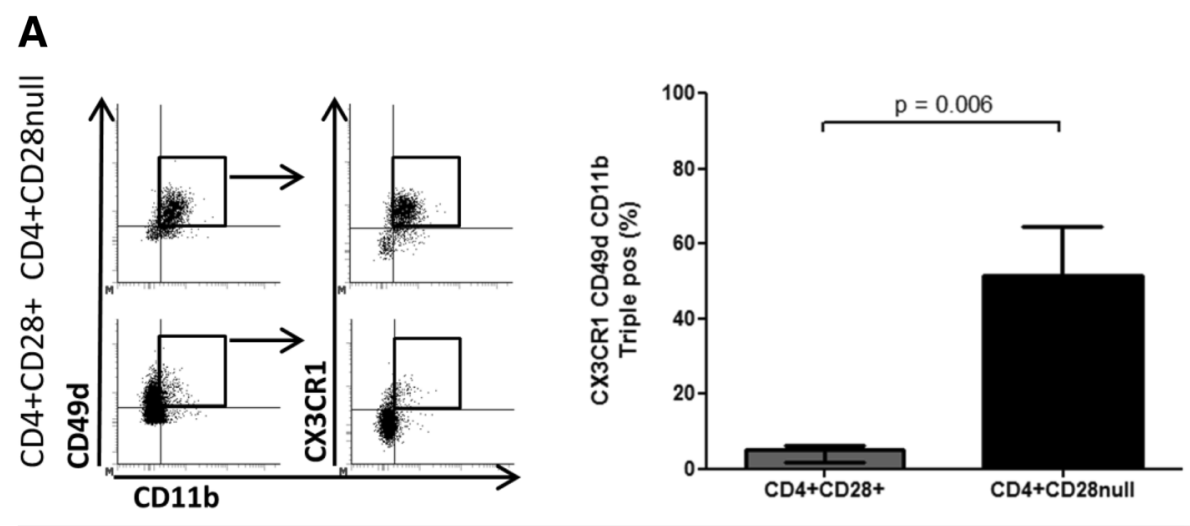

B
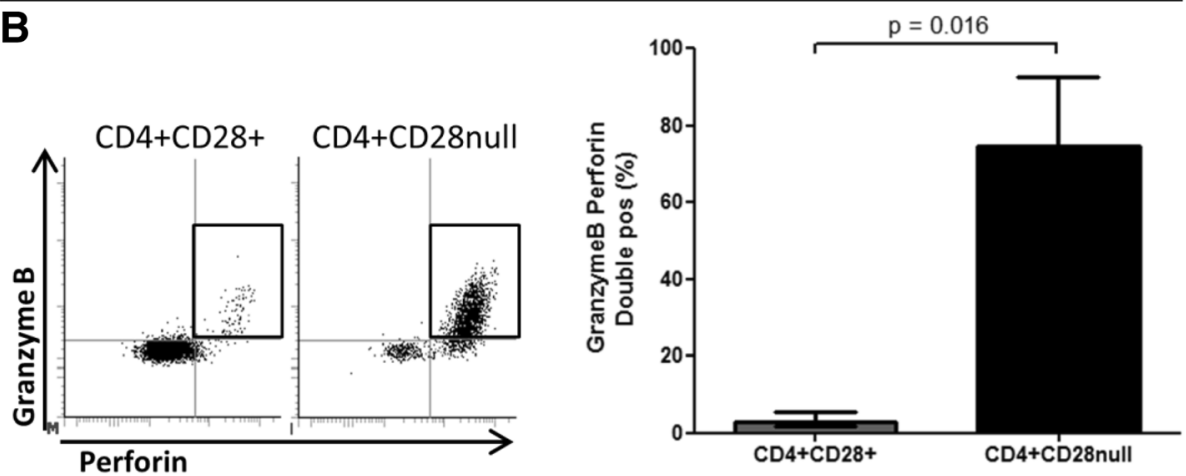

Fig. $2 \mathrm{CD}^{+} \mathrm{CD} 28^{\text {null }} \mathrm{T}$ cells are endothelial homing, cytotoxic T cells. Unstimulated CD4 T cells from patients with ANCA-associated vasculitis (AAV) $(n=10)$ were stained for expression of endothelial homing receptors CX3CR1, CD49d and CD11b and intracellular cytotoxic molecules perforin and granzyme B. a Representative staining and summary data for unstimulated CD4 T cells gated on CD4 $4^{+} \mathrm{CD} 28^{\text {null }}$ (top two flow cytometry plots) and $\mathrm{CD} 4^{+} \mathrm{CD} 28^{+} \mathrm{T}$ cells (bottom two flow cytometry plots). Sequential gating was performed as follows: CD49d and CD11b to identify CD49d CD11b double-positive cells, followed by CX3CR1 to identify CD49d CD11b CX3CR1 triple-positive cells. b Representative staining and summary data for unstimulated CD4 T cells gated on $\mathrm{CD} 4^{+} \mathrm{CD} 28^{+}$and $\mathrm{CD} 4^{+} \mathrm{CD} 28^{\text {null }} \mathrm{T}$ cells showing cells double-positive for perforin and granzyme B

analysis with a $P$ value of less than 0.1 (Tables 2 and 3 ). This demonstrated that the percentage of $\mathrm{CD} 44^{+} \mathrm{CD} 28^{\text {null }}$ $\mathrm{T}$ cells associated with increased arterial stiffness independently of age, proteinuria, peripheral mean arterial blood pressure, and plasma concentration of TNF- $\alpha$.
There was a $0.66 \mathrm{~m} / \mathrm{s}$ [95\% confidence interval 0.13-1.19] increase in PWV for every $10 \%$ increase in $\mathrm{CD} 44^{+} \mathrm{CD} 28^{\text {null }}$ $\mathrm{T}$ cells $(P=0.016$; Table 3$)$. This relationship did not change when systolic blood pressure or pulse pressure was substituted for mean arterial blood pressure, and the

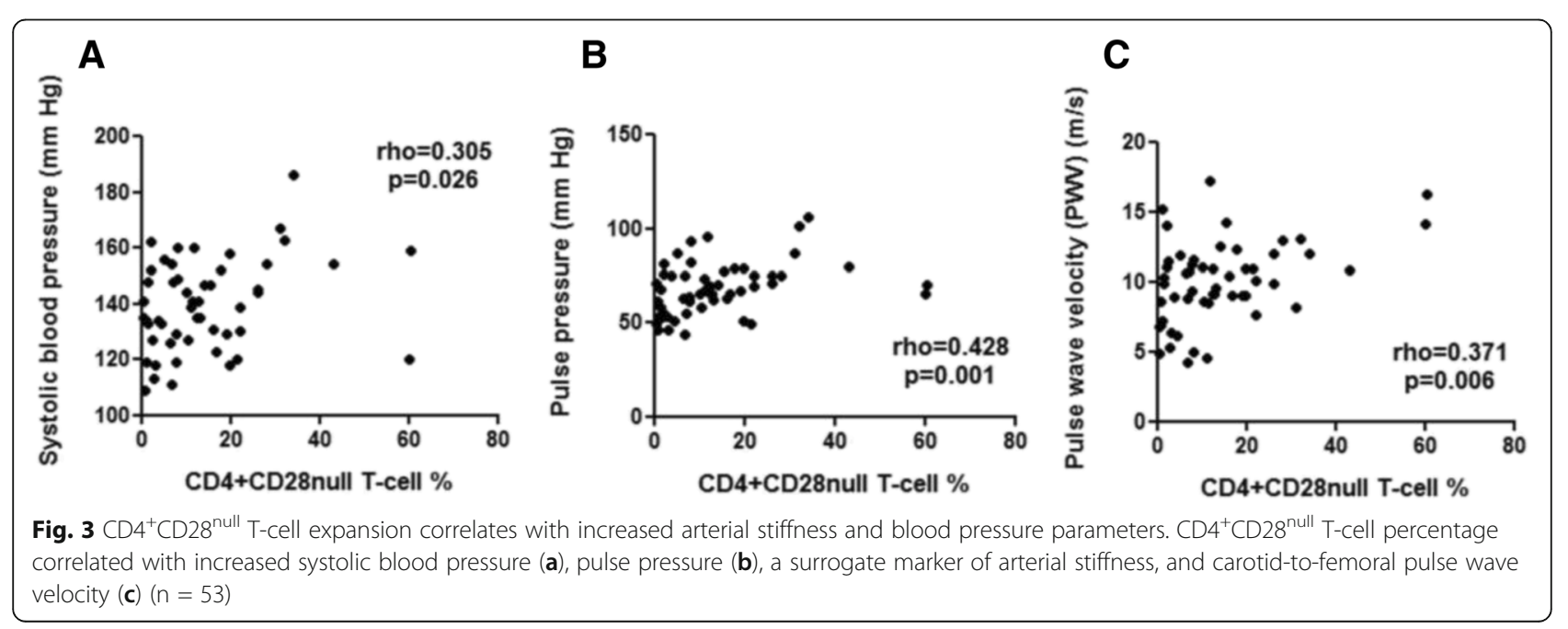


Table 2 Variables associated with pulse wave velocity on univariable analysis

\begin{tabular}{|c|c|c|c|}
\hline \multirow[t]{2}{*}{ Variable } & \multicolumn{3}{|c|}{ Univariable analysis } \\
\hline & $\overline{R^{2}}$ & Regression coefficient [95\% Cl] & $P$ value \\
\hline Age, years & 0.183 & $0.131[0.053,0.208]$ & 0.001 \\
\hline Gender & 0.004 & $0.393[-1.313,2.100]$ & 0.645 \\
\hline eGFR, mL/min per $1.73 \mathrm{~m}^{2}$ & 0.026 & $-0.023[-0.062,0.017]$ & 0.252 \\
\hline Urinary albumin-to-creatinine ratio, mg/mmol & 0.056 & $0.019[-0.003,0.041]$ & 0.088 \\
\hline Ever smoker & 0.017 & $-0.759[-2.364,0.847]$ & 0.347 \\
\hline Presence of diabetes & 0.002 & $0.291[-1.704,2.286]$ & 0.771 \\
\hline On statin treatment & 0.044 & $1.208[-0.383,2.799]$ & 0.134 \\
\hline Pulse pressure, mm Hg & 0.163 & $0.084[0.030,0.137]$ & 0.003 \\
\hline Mean arterial pressure, $\mathrm{mm} \mathrm{Hg}$ & 0.102 & $0.088[0.015,0.161]$ & 0.020 \\
\hline Systolic blood pressure, mm Hg & 0.191 & $0.079[0.033,0.124]$ & 0.001 \\
\hline Diastolic blood pressure, $\mathrm{mm} \mathrm{Hg}$ & 0.027 & $0.056[-0.039,0.150]$ & 0.243 \\
\hline $\mathrm{CD}^{+}{ }^{+} \mathrm{CD} 28^{\text {null }}$ T-cell proportion (\%), per $10 \%$ increase & 0.182 & $0.912[0.368,1.455]$ & 0.001 \\
\hline C-reactive protein, $\mathrm{mg} / \mathrm{mL}$ & 0.008 & $-0.234[-0.958,0.490]$ & 0.520 \\
\hline $\mathrm{IL}-2, \mathrm{pg} / \mathrm{mL}$ & 0.066 & $0.007[0.000,0.015]$ & 0.065 \\
\hline IFN- $\gamma, p g / m L$ & 0.036 & $-0.004[-0.010,0.002]$ & 0.179 \\
\hline IL-10, pg/mL & 0.025 & $0.089[-0.068,0.245]$ & 0.260 \\
\hline IL-6, pg/mL & 0.004 & $0.002[-0.007,0.011]$ & 0.649 \\
\hline TNF-a, pg/mL & 0.083 & $0.015[0.001,0.029]$ & 0.039 \\
\hline IL-17, pg/mL & 0.015 & $-0.003[-0.011,0.004]$ & 0.389 \\
\hline
\end{tabular}

All variables with a $P$ value of less than 0.1 on univariable analysis were included in the multivariable model shown in Table 3

Abbreviations: $\mathrm{Cl}$ confidence interval, eGFR estimated glomerular filtration rate, IL interleukin, TNF- $a$ tumour necrosis factor-alpha

size of the $\mathrm{CD} 4{ }^{+} \mathrm{CD} 28^{\text {null }} \mathrm{T}$-cell expansion remained independently associated with increased PWV.

\section{Discussion}

Our findings demonstrate that the host cellular immune response to CMV is associated with the expansion of a subset of pro-inflammatory, endothelial homing, cytotoxic $\mathrm{CD} 4{ }^{+} \mathrm{CD} 28^{\text {null }} \mathrm{T}$ cells in patients with AAV. Furthermore, the size of this expansion is independently linked to increased arterial stiffness, a marker of cardiovascular mortality [37]. This is significant in AAV as cardiovascular disease is a leading cause of death in this patient group.

Our data provide further insight into the properties of $\mathrm{CD} 4{ }^{+} \mathrm{CD} 28^{\text {null }} \mathrm{T}$ cells and their capacity to cause vascular damage of relevance to AAV. We identified $\mathrm{CD} 4{ }^{+} \mathrm{CD} 28^{\text {null }} \mathrm{T}$ cells in AAV to be Th1-skewed pro-inflammatory $\mathrm{T}$ cells that produce IFN- $\gamma$ and TNF- $\alpha$ in response to stimulation with CMV lysate. These findings are in keeping with previous reports in HVs [38] as well as in AAV where $\mathrm{CD} 44^{+} \mathrm{CD} 28^{\text {null }} \mathrm{T}$ cells have been shown to be a major source of IFN- $\gamma$ and TNF- $\alpha$ [39].

Table 3 Multivariable linear regression model for pulse wave velocity (meters per second)

\begin{tabular}{|c|c|c|c|c|}
\hline \multirow[t]{2}{*}{ Variable } & \multicolumn{2}{|l|}{ Univariable analysis } & \multicolumn{2}{|l|}{ Multivariable analysis } \\
\hline & Regression coefficient $[95 \% \mathrm{Cl}]$ & $P$ value & Regression coefficient [95\% Cl] & $P$ value \\
\hline $\mathrm{CD}^{+}{ }^{+} \mathrm{CD} 28^{\text {null }} \mathrm{T}$-cell percentage, per $10 \%$ increase & $0.912[0.368,1.455]$ & 0.001 & $0.663[0.132,1.194]$ & 0.016 \\
\hline Age, years & $0.131[0.053,0.208]$ & 0.001 & $0.080[0.006,0.155]$ & 0.035 \\
\hline Proteinuria (urinary ACR), $\mathrm{mg} / \mathrm{mmol}$ & $0.019[-0.003,0.041]$ & 0.088 & $0.013[-0.007,0.033]$ & 0.196 \\
\hline Mean arterial pressure, $\mathrm{mm} \mathrm{Hg}$ & $0.088[0.015,0.161]$ & 0.020 & $0.053[-0.016,0.122]$ & 0.128 \\
\hline TNF-a, pg/mL & $0.015[0.001,0.029]$ & 0.039 & $0.010[-0.002,0.022]$ & 0.086 \\
\hline
\end{tabular}

Variables with $P$ value of less than 0.1 on univariable analysis (Table 2) were included in the model. In order to avoid collinearity, only one blood pressure parameter and either plasma concentration of tumour necrosis factor-alpha (TNF-a) or interleukin-2 (IL-2) were added at each iteration of the model. This table shows the final model with mean arterial pressure (MAP) and TNF-a. The size of the $C D 4^{+} C D 28^{\text {null }}$ T-cell expansion remained independently associated with pulse wave velocity with negligible impact on the model characteristics when pulse pressure or systolic blood pressure was substituted for MAP and when plasma concentration of IL-2 was substituted for TNF-a

$R$ value: $0.635, R^{2}: 0.404$

Abbreviations: $A C R$ albumin-to-creatinine ratio, $C l$ confidence interval 
Th1 $\mathrm{T}$ cells are recognised as important players in the atherosclerotic process with Th1-driven responses exerting detrimental effects [40]. Mice deficient in T-bet, the master regulator of the Th1 transcriptional response, are relatively protected from the development of atherosclerotic lesions [35], and both T-bet and IFN- $\gamma$ are essential in the generation of angiotensin II-mediated vascular dysfunction [41]. We observed that the CD4 Th1 compartment in AAV CMV-seropositive patients was made up mostly of $\mathrm{CD} 44^{+} \mathrm{CD} 28^{\text {null }} \mathrm{T}$ cells and that up to $94 \%$ of Th1 cells were $\mathrm{CD} 4{ }^{+} \mathrm{CD} 28^{\text {null }}$. Taken together, our findings indicate that CMV exerts a powerful influence on the shape and magnitude of the Th1 repertoire.

IFN- $\gamma$ and TNF- $\alpha$ cytokines mediate inflammation in blood vessel walls through disruption of endothelial junctions and induction of chemokine and adhesion molecule expression on vascular endothelium. This promotes the recruitment and adherence of lymphocytes and monocytes on the inflamed endothelium and facilitates leukocyte transmigration [36]. In our phenotypic analysis, $\mathrm{CD} 44^{+} \mathrm{CD} 28^{\text {null }} \mathrm{T}$ cells were found to express the chemokine receptors CX3CR1, CD49d, CD11b and CXCR3 that are able to bind their respective adhesion molecule ligands fractalkine, VCAM-1, ICAM-1 and IP-10 on activated endothelial cells [42, 43]. They also co-expressed the cytolytic granules granzyme B and perforin, as previously found by others [44], suggesting that they act as cytotoxic effector cells. The endothelium is an important site for CMV infection [27] and as such endothelial targeting by CMV-specific $\mathrm{T}$ cells would be expected to have the capacity to suppress viral reactivation but might also contribute to vascular damage.

Consistent with these observations, our findings revealed that the size of the $\mathrm{CD} 44^{+} \mathrm{CD} 28^{\text {null }} \mathrm{T}$-cell expansion in patients with AAV was independently associated with increased arterial stiffness. This is contrary to a recent report in patients with AAV where the size of the $\mathrm{CD} 4{ }^{+} \mathrm{CD} 28^{\text {null }} \mathrm{T}$-cell expansion was found not to be related to arterial stiffness [45]. However, the AAV cohort within that study included a substantial proportion of CMV-seronegative patients and only 24 patients were CMV-seropositive. Given that significant expansion of $\mathrm{CD} 4{ }^{+} \mathrm{CD} 28^{\text {null }} \mathrm{T}$ cells is seen mainly in CMV-seropositive individuals, this may explain the discrepancy between our findings and those of Slot et al. [45]. Furthermore, our data are in agreement with several published studies reporting associations in other patient groups such as rheumatoid arthritis [15] and chronic kidney disease [18], between $\mathrm{CD}^{+} \mathrm{CD} 28^{\text {null }} \mathrm{T}$ cells and markers of atherosclerotic damage.

Previous work by our group has shown that CMV-seropositive patients with chronic kidney disease have stiffer arteries compared with CMV-seronegative chronic kidney disease patients [30]. In the present study, we observed that expansion of $\mathrm{CD} 4{ }^{+} \mathrm{CD} 28^{\text {null }} \mathrm{T}$ cells in CMV-seropositive AAV patients is associated with increased arterial stiffness in that carotid-to-femoral PWV increases by $0.66 \mathrm{~m} / \mathrm{s}$ for every $10 \%$ increase in the size of the $\mathrm{CD} 4^{+} \mathrm{CD} 28^{\text {null }} \mathrm{T}$-cell subset. Such an effect size on PWV is greater than the impact of smoking on arterial stiffness [46] and roughly equivalent to 10 years' worth of ageing [47]. In contrast, we found no correlation between the humoral response to $\mathrm{CMV}$, measured by the anti-CMV IgG titre, and arterial stiffness. Based on our data, we propose that the host cellular immune response to CMV is directly involved in the development of cardiovascular pathology and that this is driven by the expansion of the pro-inflammatory endothelial homing $\mathrm{CD}_{4}^{+}$ CD28 $8^{\text {null }}$ T-cell subset. However, it should be noted that our study was cross-sectional in nature and therefore cannot definitively confirm a longitudinal increase in arterial stiffness driven by $\mathrm{CD} 4{ }^{+} \mathrm{CD} 28^{\text {null }} \mathrm{T}$ cells.

It is likely that expansion of $\mathrm{CD} 4^{+} \mathrm{CD} 28^{\text {null }} \mathrm{T}$ cells itself is driven by asymptomatic subclinical reactivation of CMV. Viral reactivation is more likely to occur in an inflammatory milieu, and TNF- $\alpha$ has recently been shown to reverse the transcriptional silencing that maintains CMV latency, leading to lytic reactivation [48]. We recently observed that subclinical CMV reactivation occurs in over a quarter of patients with AAV in remission within a 12-month period [49], indicating that CMV reactivation is a frequent event in this patient group. This could explain our finding that $\mathrm{CD} 44^{+} \mathrm{CD} 28^{\text {null }} \mathrm{T}$-cell expansions are almost twice as large in AAV patients compared with age-matched HVs. Subclinical CMV reactivation is likely to be even higher during the acute phase of AAV, when patients are exposed to high levels of systemic inflammation and intensive immunosuppressive treatment. As viral reactivation is expected to act as a potent stimulus for boosting the CMV-specific cellular immune response, anti-viral therapy could act to suppress CMV-specific immune responses and potentially reduce cardiovascular damage. Anti-viral therapy in this context would suppress all herpes viruses. This could be advantageous as recent evidence suggests that concomitant CMV and Epstein-Barr virus infection may be associated with increased expansion of $\mathrm{CD} 4{ }^{+} \mathrm{CD} 28^{\text {null }} \mathrm{T}$ cells in AAV [50].

\section{Conclusions}

In summary, the results presented here support a mechanism for vascular damage secondary to expansion of pro-inflammatory $\mathrm{CMV}$-specific $\mathrm{T}$ cells that target the endothelium and are independently linked to arterial stiffness. Our data suggest that suppression of CMV may hold therapeutic potential for patients with AAV, 
lending support to the design of further studies aiming to determine whether CMV suppression might reduce expansion of $\mathrm{CD} 44^{+} \mathrm{CD} 28^{\text {null }} \mathrm{T}$ cells, ameliorating surrogate markers of atherosclerotic damage, and ultimately reducing risk of cardiovascular disease, the leading cause of death in this patient group.

\section{Additional file}

Additional file 1: Table S1. Antibodies used for flow cytometric analysis. Figure S1. Gating strategy for whole blood staining. Figure S2. Gating strategy for cytomegalovirus (CMV) lysate-stimulated peripheral blood mononuclear cells (PBMC). (DOCX 687 kb)

\section{Abbreviations}

AAV: ANCA-associated vasculitis; ANCA: Anti-neutrophil cytoplasmic antibody; CMV: Cytomegalovirus; CVD: Cardiovascular disease; CX3CR1: CX3C chemokine receptor $1 ; \mathrm{HV}$ : Healthy volunteer; ICAM-1: Intercellular adhesion molecule 1; IFN-ү: Interferon-gamma; IL: Interleukin; IP-10: IFN-gammainducible protein 10; PBMC: Peripheral blood mononuclear cell; PWV: Pulse wave velocity; Th: T helper; TNF-a: Tumour necrosis factor-alpha; VCAM1: Vascular cell adhesion molecule 1

\section{Acknowledgements}

The study was conducted within the Birmingham National Institute for Health Research (NIHR)/Wellcome Trust (WT) Clinical Research Facility (CRF) (Birmingham, UK). The views expressed are those of the authors and not necessarily those of the NHS, the NIHR or the Department of Health. Parts of this work have been presented in abstract form at a scientific meeting or published as a conference abstract or both.

\section{Funding}

This research was funded by a Wellcome Trust Research Training Fellowship Grant (097962/Z/11/Z) and by Vasculitis UK. The funding sources had no role in the design and conduct of the study; collection, management, analysis and interpretation of the data; preparation, review, or approval of the manuscript; or decision to submit the manuscript for publication.

\section{Availability of data and materials}

The datasets analysed during the current study are available from the corresponding author on reasonable request.

\section{Authors' contributions}

DC, LH, MDM, PM and CF conceived and designed the study. DC, MS, LD, PS, $L P, S J$ and JB acquired data. DC, MS, PN, CF and LH analysed and interpreted data. DC drafted the manuscript. All authors critically revised the manuscript and approved the final version.

\section{Ethics approval and consent to participate}

The study was approved by the Research Ethics Committee of Yorkshire and the Humber (UK). Written informed consent was obtained from all participants.

\section{Consent for publication}

Not applicable.

\section{Competing interests}

The authors declare that they have no competing interests.

\section{Publisher's Note}

Springer Nature remains neutral with regard to jurisdictional claims in published maps and institutional affiliations.

\section{Author details}

'Institute of Inflammation and Ageing, College of Medical and Dental Sciences, University of Birmingham, Birmingham B15 2TT, UK. ${ }^{2}$ Renal Unit, University Hospitals Birmingham NHS Foundation Trust, Mindelsohn Way, Edgbaston, Birmingham B15 2TH, UK. ${ }^{3}$ Institute of Translational Medicine
Birmingham, Heritage Building, Mindelsohn Way, Edgbaston, Birmingham B15 2TH, UK. ${ }^{4}$ Institute of Clinical Sciences, College of Medical and Dental Sciences, University of Birmingham, Birmingham B15 2T, UK. Institute of Immunology and Immunotherapy, College of Medical and Dental Sciences, University of Birmingham, Birmingham B15 2TT, UK.

Received: 23 April 2018 Accepted: 1 August 2018

Published online: 29 August 2018

\section{References}

1. Brown W, Remaley AT, Ridker PM. JCL roundtable: is inflammation a future target in preventing arteriosclerotic cardiovascular disease. J Clin Lipidol. 2015:9(2):119-28.

2. Ridker PM, Everett BM, Thuren T, MacFadyen JG, Chang WH, Ballantyne C, et al. Antiinflammatory therapy with Canakinumab for atherosclerotic disease. N Engl J Med. 2017;377(12):1119-31.

3. Goodson NJ, Wiles NJ, Lunt M, Barrett EM, Silman AJ, Symmons DP. Mortality in early inflammatory polyarthritis: cardiovascular mortality is increased in seropositive patients. Arthritis Rheum. 2002;46(8):2010-9.

4. Thomas G, Mancini J, Jourde-Chiche N, Sarlon G, Amoura Z, Harle JR, et al. Mortality associated with systemic lupus erythematosus in France assessed by multiple-cause-of-death analysis. Arthritis Rheum. 2014:66(9):2503-11.

5. Flossmann O, Berden A, de Groot K, Hagen C, Harper L, Heijl C, et al. Longterm patient survival in ANCA-associated vasculitis. Ann Rheum Dis. 2011; 70(3):488-94.

6. del Rincon ID, Williams K, Stern MP, Freeman GL, Escalante A. High incidence of cardiovascular events in a rheumatoid arthritis cohort not explained by traditional cardiac risk factors. Arthritis Rheum. 2001;44(12): 2737-45.

7. Hansson GK. Inflammation, atherosclerosis, and coronary artery disease. N Engl J Med. 2005;352(16):1685-95.

8. Liuzzo G, Kopecky SL, Frye RL, O'Fallon WM, Maseri A, Goronzy JJ, et al. Perturbation of the T-cell repertoire in patients with unstable angina. Circulation. 1999;100(21):2135-9.

9. Schmidt D, Goronzy J, Weyand CM. CD4+ CD7- CD28- T cells are expanded in rheumatoid arthritis and are characterized by autoreactivity. J Clin Invest. 1996:97(9):2027-37.

10. Ugarte-Gil MF, Sanchez-Zuniga C, Gamboa-Cardenas RV, Aliaga-Zamudio M, Zevallos F, Tineo-Pozo G, et al. Circulating CD4+CD28 $8^{\text {null }}$ and extra-thymic CD4+CD8+ double positive T cells are independently associated with disease damage in systemic lupus erythematosus patients. Lupus. 2016; 25(3):233-40.

11. Thewissen M, Somers V, Hellings $N$, Fraussen J, Damoiseaux J, Stinissen P. CD4+CD28 ${ }^{\text {null }} T$ cells in autoimmune disease: pathogenic features and decreased susceptibility to immunoregulation. J Immunol. 2007;179(10): 6514-23.

12. Liuzzo G, Goronzy JJ, Yang H, Kopecky SL, Holmes DR, Frye RL, et al. Monoclonal T-cell proliferation and plaque instability in acute coronary syndromes. Circulation. 2000;101(25):2883-8.

13. Nakajima T, Schulte S, Warrington KJ, Kopecky SL, Frye RL, Goronzy JJ, et al, T-cell-mediated lysis of endothelial cells in acute coronary syndromes. Circulation. 2002;105(5):570-5.

14. de Menthon M, Lambert M, Guiard E, Tognarelli S, Bienvenu B, Karras A, et al. Excessive interleukin-15 transpresentation endows NKG2D+CD4+ T cells with innate-like capacity to lyse vascular endothelium in granulomatosis with polyangiitis (Wegener's). Arthritis Rheum. 2011;63(7):2116-26.

15. Gerli R, Schillaci G, Giordano A, Bocci EB, Bistoni O, Vaudo G, et al. CD4 +CD28- T lymphocytes contribute to early atherosclerotic damage in rheumatoid arthritis patients. Circulation. 2004:109(22):2744-8.

16. Betjes MG, Meijers RW, de Wit LE, Litjens NH. A killer on the road: circulating CD4(+)CD28 $8^{\text {null }} T$ cells as cardiovascular risk factor in ESRD patients. J Nephrol. 2012;25(2):183-91

17. Lopez P, Rodriguez-Carrio J, Martinez-Zapico A, Caminal-Montero L, Suarez A. Senescent profile of angiogenic T cells from systemic lupus erythematosus patients. J Leukoc Biol. 2016;99(3):405-12

18. Yadav AK, Banerjee D, Lal A, Jha V. Vitamin D deficiency, CD4+CD28 ${ }^{\text {null }}$ cells and accelerated atherosclerosis in chronic kidney disease. Nephrology. 2012; 17(6):575-81.

19. Pera A, Broadley I, Davies KA, Kern F. Cytomegalovirus as a driver of excess cardiovascular mortality in rheumatoid arthritis: a red herring or a smoking gun? Circ Res. 2017;120(2):274-7. 
20. Schmidt D, Martens PB, Weyand CM, Goronzy JJ. The repertoire of CD4+ CD28- T cells in rheumatoid arthritis. Mol Med. 1996;2(5):608-18.

21. Morgan MD, Pachnio A, Begum J, Roberts D, Rasmussen N, Neil DA, et al. CD4 +CD28- T cell expansion in granulomatosis with polyangiitis (Wegener's) is driven by latent cytomegalovirus infection and is associated with an increased risk of infection and mortality. Arthritis Rheum. 2011;63(7):2127-37.

22. Eriksson P, Sandell C, Backteman K, Ernerudh J. Expansions of CD4+CD28and CD8+CD28- $T$ cells in granulomatosis with polyangiitis and microscopic polyangiitis are associated with cytomegalovirus infection but not with disease activity. J Rheumatol. 2012;39(9):1840-3.

23. Shabir S, Smith H, Kaul B, Pachnio A, Jham S, Kuravi S, et al.

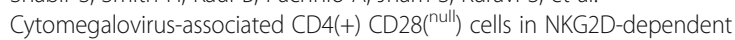
glomerular endothelial injury and kidney allograft dysfunction. Am J Transplant Off J Am Soc Transplant Am Soc Transplant Surg. 2016;16(4): 1113-28.

24. Hooper M, Kallas EG, Coffin D, Campbell D, Evans TG, Looney RJ. Cytomegalovirus seropositivity is associated with the expansion of CD4 +CD28- and CD8+CD28- T cells in rheumatoid arthritis. J Rheumatol. 1999; 26(7):1452-7.

25. Bate SL, Dollard SC, Cannon MJ. Cytomegalovirus seroprevalence in the United States: the national health and nutrition examination surveys, 19882004. Clin Infect Dis. 2010;50(11):1439-47.

26. Spyridopoulos I, Martin-Ruiz C, Hilkens C, Yadegarfar ME, Isaacs J, Jagger C, et al. CMV seropositivity and T-cell senescence predict increased cardiovascular mortality in octogenarians: results from the Newcastle 85+ study. Aging Cell. 2016;15(2):389-92.

27. Pampou S, Gnedoy SN, Bystrevskaya VB, Smirnov VN, Chazov El, Melnick JL, et al. Cytomegalovirus genome and the immediate-early antigen in cells of different layers of human aorta. Virchows Archiv. 2000;436(6):539-52.

28. Haarala A, Kahonen M, Lehtimaki T, Aittoniemi J, Jylhava J, Hutri-Kahonen N, et al. Relation of high cytomegalovirus antibody titres to blood pressure and brachial artery flow-mediated dilation in young men: the cardiovascular risk in young Finns study. Clin Exp Immunol. 2012;167(2):309-16.

29. Firth C, Harrison R, Ritchie S, Wardlaw J, Ferro CJ, Starr JM, et al. Cytomegalovirus infection is associated with an increase in systolic blood pressure in older individuals. QJM. 2016;109(9):595-600.

30. Wall NA, Chue CD, Edwards NC, Pankhurst T, Harper L, Steeds RP, et al. Cytomegalovirus seropositivity is associated with increased arterial stiffness in patients with chronic kidney disease. PLoS One. 2013;8(2):e55686.

31. Wang H, Peng G, Bai J, He B, Huang K, Hu X, Liu D. Cytomegalovirus infection and relative risk of cardiovascular disease (ischemic heart disease, stroke, and cardiovascular death): a meta-analysis of prospective studies up to 2016. J Am Heart Assoc. 2017;6(7):e005025.

32. Chanouzas D, Dyall L, Nightingale P, Ferro C, Moss P, Morgan MD, et al. Valaciclovir to prevent Cytomegalovirus mediated adverse modulation of the immune system in ANCA-associated vasculitis (CANVAS): study protocol for a randomised controlled trial. Trials. 2016;17(1):338. https://doi.org/10. 1186/s13063-13016-11482-13062.

33. Chattopadhyay PK, Yu J, Roederer M. Live-cell assay to detect antigen-specific CD4+ T-cell responses by CD154 expression. Nat Protoc. 2006;1(1):1-6.

34. Becattini S, Latorre D, Mele F, Foglierini M, De Gregorio C, Cassotta A, et al. $T$ cell immunity. Functional heterogeneity of human memory CD4(+) T cell clones primed by pathogens or vaccines. Science. 2015;347(6220):400-6.

35. Buono C, Binder CJ, Stavrakis G, Witztum JL, Glimcher LH, Lichtman AH. Tbet deficiency reduces atherosclerosis and alters plaque antigen-specific immune responses. Proc Natl Acad Sci U S A. 2005;102(5):1596-601.

36. Ait-Oufella $H$, Taleb S, Mallat Z, Tedgui A. Recent advances on the role of cytokines in atherosclerosis. Arterioscler Thromb Vasc Biol. 2011;31(5):969-79.

37. Chue CD, Townend JN, Steeds RP, Ferro CJ. Arterial stiffness in chronic kidney disease: causes and consequences. Heart. 2010;96(11):817-23.

38. Pachnio A, Ciaurriz M, Begum J, Lal N, Zuo J, Beggs A, et al. Cytomegalovirus infection leads to development of high frequencies of cytotoxic virus-specific CD4+ T cells targeted to vascular endothelium. PLoS Pathog. 2016;12(9):e1005832.

39. Komocsi A, Lamprecht P, Csernok E, Mueller A, Holl-Ulrich K, Seitzer U, et al. Peripheral blood and granuloma CD4(+)CD28(-) T cells are a major source of interferon-gamma and tumor necrosis factor-alpha in Wegener's granulomatosis. Am J Pathol. 2002;160(5):1717-24.

40. Mallat Z, Taleb S, Ait-Oufella H, Tedgui A. The role of adaptive T cell immunity in atherosclerosis. J Lipid Res. 2009;50(Suppl):S364-9.
41. Kossmann S, Schwenk M, Hausding M, Karbach SH, Schmidgen MI, Brandt $\mathrm{M}$, et al. Angiotensin I--induced vascular dysfunction depends on interferongamma-driven immune cell recruitment and mutual activation of monocytes and NK-cells. Arterioscler Thromb Vasc Biol. 2013;33(6):1313-9.

42. van de Berg PJ, Yong SL, Remmerswaal EB, van Lier RA, ten Berge IJ. Cytomegalovirus-induced effector T cells cause endothelial cell damage. Clin Vaccine Immunol. 2012;19(5):772-9.

43. Bolovan-Fritts CA, Trout RN, Spector SA. High T-cell response to human cytomegalovirus induces chemokine-mediated endothelial cell damage. Blood. 2007;110(6):1857-63.

44. Dumitriu IE. The life (and death) of CD4+ CD28( $\left.{ }^{\text {null }}\right)$ T cells in inflammatory diseases. Immunology. 2015;146(2):185-93.

45. Slot MC, Kroon AA, Damoiseaux J, Theunissen R, Houben A, de Leeuw PW, et al. CD4+CD28 ${ }^{\text {null }} T$ cells are related to previous cytomegalovirus infection but not to accelerated atherosclerosis in ANCA-associated vasculitis. Rheumatol Int. 2017;37(5):791-8.

46. Reference Values for Arterial Stiffness C. Determinants of pulse wave velocity in healthy people and in the presence of cardiovascular risk factors: 'establishing normal and reference values'. Eur Heart J. 2010;31(19):2338-50.

47. McEniery CM, Yasmin HIR, Qasem A, Wilkinson IB, Cockcroft JR, Investigators A. Normal vascular aging: differential effects on wave reflection and aortic pulse wave velocity: the Anglo-Cardiff collaborative trial (ACCT). J Am Coll Cardiol. 2005;46(9):1753-60.

48. Rauwel B, Jang SM, Cassano M, Kapopoulou A, Barde I, Trono D. Release of human cytomegalovirus from latency by a KAP1/TRIM28 phosphorylation switch. eLife. 2015;4 https://doi.org/10.7554/eLife.06068.

49. Chanouzas D, Sagmeister M, Faustini S, Nightingale P, Richter A, Ferro CJ, Morgan MD, Moss P, Harper L. Subclinical reactivation of cytomegalovirus drives CD4+CD28null T-cell expansion and impaired immune response to pneumococcal vaccination in ANCA-associated vasculitis. J Infect Dis. 2018.

50. Kerstein A, Schuler S, Cabral-Marques O, Fazio J, Hasler R, Muller A, et al. Environmental factor and inflammation-driven alteration of the total peripheral T-cell compartment in granulomatosis with polyangiitis. J Autoimmun. 2017;78:79-91.

Ready to submit your research? Choose BMC and benefit from:

- fast, convenient online submission

- thorough peer review by experienced researchers in your field

- rapid publication on acceptance

- support for research data, including large and complex data types

- gold Open Access which fosters wider collaboration and increased citations

- maximum visibility for your research: over $100 \mathrm{M}$ website views per year

At BMC, research is always in progress.

Learn more biomedcentral.com/submissions 